\title{
Surfactant Therapy and High-Frequency Jet Ventilation in the Management of a Piglet Model of the Meconium Aspiration Syndrome ${ }^{1}$
}

\author{
THOMAS E. WISWELL, SAMUEL S. PEABODY, JONATHAN M. DAVIS, \\ MICHAEL V. SLAYTER, REBECCA C. BENT, AND T. ALLEN MERRITT \\ Thomas Jefferson University, Philadelphia, Pennsylvania 19107 [T.E.W.]; the Walter Reed Army \\ Medical Center [R.C.B.] and the Armed Forces Institute of Pathology [S.S.P., M.V.S.], \\ Washington, DC 20307; Winthrop-University Hospital (State University of New York Stony \\ Brook), Mineola, New York 11501 [J.M.D.]; and University of California Davis, Sacramento, \\ California 95817 [T.A.M.]
}

\section{ABSTRACT}

In vitro data have shown a concentration-dependent inhibition of surfactant by meconium, while anecdotal reports demonstrate improved oxygenation after surfactant replacement in babies with meconium aspiration syndrome, particularly in conjunction with high-frequency jet ventilation. We randomized 70 newborn piglets to either conventional or high-frequency jet ventilation, followed by insufflation of $3 \mathrm{~mL} / \mathrm{kg}$ of a $33 \%$ meconium solution. Each group was further randomized to one of five surfactant therapies: 1) control, 2) $4 \mathrm{~mL} / \mathrm{kg}$ Survanta, 3) $8 \mathrm{~mL} / \mathrm{kg}$ Survanta, 4) $5 \mathrm{~mL} / \mathrm{kg}$ Exosurf, or 5) $10 \mathrm{~mL} / \mathrm{kg}$ Exosurf. We followed arterial blood gases and ventilator requirements over $6 \mathrm{~h}$ of ventilation. Aspirates of airway fluids were obtained for surface tension measurements, as well as total protein and phospholipid concentrations. Using a previously established scoring system, a pathologist blinded to treatment evaluated four sections of lung per animal for histologic changes of meconium aspiration syndrome. There were no differences noted between groups in any physiologic parameter measured (mean airway pressure, arterial partial pressure of oxygen/alveolar partial pressure of oxygen ratio, etc.) during the $6 \mathrm{~h}$ of ventilation. Airway fluid aspirate total protein concentrations increased significantly after meconium instillation (4- to 5-fold, $p<0.007$ ) and remained elevated in spite of surfactant therapy. There was an initial decline in airway phospholipid concentra- tions after meconium instillation followed by a rise to levels equal to or greater than premeconium levels. Surface tension measurements increased in all groups after meconium insufflation $(p<0.012)$ and did not decline thereafter, despite standard and twice-standard surfactant doses of both types. Histology of surfactant-treated animals was similar to that of control piglets regardless of ventilator management. Five of 56 animals receiving surfactant had overt pulmonary hemorrhage. These data suggest that surfactant therapy with or without high-frequency jet ventilation in this animal model of meconium aspiration syndrome does not improve oxygenation, surface tension, or lung histology. (Pediatr Res 36: 494-500, 1994)
Abbreviations
$\mathrm{FiO}_{2}$, fraction of inspired oxygen
JET, high-frequency jet ventilation
MAS, meconium aspiration syndrome
Paw, mean airway pressure
$\mathbf{P a c o}_{2}$, arterial partial pressure of carbon dioxide
$\mathbf{P a O}_{2}$, arterial partial pressure of oxygen
$\mathbf{P A O}_{2}$, alveolar partial pressure of oxygen
PEEP, positive end-expiratory pressure
PIP, peak inspiratory pressure
PPV, conventional positive pressure ventilation

The MAS is a major cause of respiratory distress among neonates (20 000-30 000 babies are affected annu-

Received August 16, 1993; accepted May 14, 1994.

Correspondence and reprint requests: Thomas E. Wiswell, M.D., Division of Neonatology, Department of Pediatrics, Thomas Jefferson University, 1025 Walnut St., Suite 700, Philadelphia, PA 19107.

Supported by the Department of Clinical Investigation of the Walter Reed Army Medical Center.

'The opinions or assertions contained herein are solely those of the authors and are not to be construed as official or as reflecting the views of the Department of the Army or the Department of Defense. ally in the United States) (1). Classically, the pathophysiology of the disorder was thought to be due to the obstructive effects of meconium $(1,2)$, with atelectasis as well as overexpansion of airways frequently occurring. However, Chen et al. (3) and Clark et al. (4) suggested a role for surfactant dysfunction in the pathogenesis of the atelectasis seen in MAS. Furthermore, Moses et al. (5) described a concentration-dependent inhibition of surfactant by meconium. They suggested that more severely affected infants with MAS might respond to higher than 
standard doses of surfactant. The anecdotal report of Auten et al. (6) described improved oxygenation after surfactant therapy among seven infants with MAS. These investigators used the standard doses received by premature infants with respiratory distress syndrome. Davis $e t$ al. (7) found the combination of JET and exogenous surfactant to result in a sustained improvement in oxygenation in 13 neonates with MAS. In a piglet model of MAS, we found less severe pathologic alterations with JET compared with conventional mechanical ventilation (8).

To date there have been no published randomized, prospective trials assessing the use of various surfactant doses, with either conventional ventilation or JET, in the management of MAS. We performed this investigation to assess the effects of different doses of two types of surfactant (one synthetic, one modified natural) in conjunction with either conventional ventilation or JET in the management of a piglet model of MAS.

\section{METHODS}

Animal preparation. We sedated 70 mixed-breed piglets, aged $1-5 \mathrm{~d}$ and weighing 1.7 to $2.9 \mathrm{~kg}$, with an intramuscular injection of ketamine hydrochloride $(20$ $\mathrm{mg} / \mathrm{kg})$ and xylazine hydrochloride $(2 \mathrm{mg} / \mathrm{kg})$. The animals were then anesthetized with $15 \mathrm{mg} / \mathrm{kg}$ of i.v. sodium pentobarbital. Doses of the pentobarbital $(5$ to $10 \mathrm{mg} / \mathrm{kg}$ ) were subsequently administered i.v. throughout the experiment as necessary to prevent spontaneous respirations. The animals were intubated with either $3.0-\mathrm{mm}$ endotracheal tubes with distal pressure-monitoring lumens (Mallinckrodt Critical Care, Glens Falls, NY) or 3.0-mm triple-lumen Hi-Lo Jet Tracheal Tubes (Mallinckrodt, Inc., St. Louis, MO). The latter tube type was used in those animals that were randomized to JET. The piglets were initially placed on a conventional infant mechanical ventilator (BabyBird 2A, 3M Corp., St. Paul, $\mathrm{MN}$ ). The initial PPV settings were as follows: $\mathrm{FiO}_{2}$, 0.25 ; rate, 15 breaths/min; PIP, $1.45 \mathrm{kPa}\left(15 \mathrm{~cm} \mathrm{H}_{2} \mathrm{O}\right)$; PEEP, $0.39 \mathrm{kPa}\left(4 \mathrm{~cm} \mathrm{H}_{2} \mathrm{O}\right)$; inspiratory time, $0.4 \mathrm{~s}$; and Paw, $0.48 \mathrm{kPa}\left(5 \mathrm{~cm} \mathrm{H}_{2} \mathrm{O}\right)$. The carotid artery was cannulated for blood sampling. Heart rate and arterial blood pressure were measured continuously. An external jugular catheter was inserted for infusion of fluids and medications. Ringers's lactate in 5\% dextrose at a rate of 6 $\mathrm{mL} / \mathrm{kg} / \mathrm{h}$ was infused i.v. continuously. The arterial line was periodically flushed with $0.5 \mathrm{~mL}$ of a solution of $0.9 \%$ sodium chloride containing $2 \mathrm{U} / \mathrm{mL}$ heparin. After the animals were stable for approximately $20 \mathrm{~min}$, an arterial blood gas measurement was obtained. Arterial blood gas specimens were analyzed using a $\mathrm{pH} / \mathrm{blood}$ gas analyzer (IL 1306, Instrumentation Laboratories, Hudson, MA).

Protocol. We obtained first-pass meconium samples from 25 term-gestation, healthy neonates. These were pooled, processed in a blender to a uniform consistency, and divided into $10-\mathrm{mL}$ aliquots that were frozen until approximately $1 \mathrm{~h}$ before each experiment when they were thawed for use. Using a self-inflating anesthesia bag, we insufflated $3.0 \mathrm{~mL} / \mathrm{kg}$ of a $33 \%$ human meconium solution into the trachea of each piglet during a 30-s period via an $8 \mathrm{~F}$ feeding catheter placed inside the endotracheal tube. Depending on the group to which they had been originally randomized before intubation, animals either continued on PPV or were managed with JET (Bunnell Life Pulse, Bunnell, Inc., Salt Lake City, UT). Immediately after meconium insufflation, the PPV settings were increased to the following: $\mathrm{FiO}_{2}, 0.75$; rate, 30 breaths/min; PIP, $2.03 \mathrm{kPa}\left(21 \mathrm{~cm} \mathrm{H}_{2} \mathrm{O}\right)$; PEEP, $0.39 \mathrm{kPa}$ $\left(4 \mathrm{~cm} \mathrm{H}_{2} \mathrm{O}\right.$ ); inspiratory time, $0.40 \mathrm{~s}$; and $\mathrm{Paw}, 0.78 \mathrm{kPa}$ $\left(8 \mathrm{~cm} \mathrm{H}_{2} \mathrm{O}\right)$. The initial settings on the high-frequency jet ventilator included $\mathrm{FiO}_{2}, 0.75$; frequency, 420 breaths/ min; “on time," $0.02 \mathrm{~s}$; PIP, $1.45 \mathrm{kPa}\left(15 \mathrm{~cm} \mathrm{H}_{2} \mathrm{O}\right)$; PEEP, $0.43 \mathrm{kPa}\left(4.5 \mathrm{~cm} \mathrm{H} \mathrm{H}_{2} \mathrm{O}\right)$; and Paw, $0.78 \mathrm{kPa}(8 \mathrm{~cm}$ $\mathrm{H}_{2} \mathrm{O}$ ). With the 35 JET piglets, a background PPV rate of 5 breaths/min, with a PIP $0.29-0.48 \mathrm{kPa}\left(3-5 \mathrm{~cm} \mathrm{H}_{2} \mathrm{O}\right)$ below that of the high-frequency jet ventilator, was used in an attempt to prevent or mitigate atelectasis. The Paw at the end of the endotracheal tubes was continuously monitored. The JET strategy was that recommended by the manufacturer.

One $\mathrm{h}$ after meconium administration, an arterial blood gas sample was obtained and surfactant administered. We used the data of Auten et al. (6) to calculate our sample size. We assumed there would be an improvement in the $\mathrm{PaO}_{2} / \mathrm{PAo}_{2}$ ratio similar to the one they found, an increase from a value of approximately 0.09 to 0.24 $1 \mathrm{~h}$ after surfactant therapy. Controlling for the probability of a type I error $(\alpha)$ of 0.05 , a sample of six piglets per group would have an $80 \%$ power of detecting a difference in the $\mathrm{PaO}_{2} / \mathrm{PAO}_{2}$ ratio of at least 0.15 between surfactanttreated subjects and controls. In the event an animal died or had to be removed from data analysis, we included one additional piglet for a total of seven per group. The 35 animals in each of the PPV and JET groups were randomized to one of five surfactant treatments: 1) control (no surfactant); 2) $4 \mathrm{~mL} / \mathrm{kg}$ Survanta (Ross Laboratories, Columbus, OH); 3) $8 \mathrm{~mL} / \mathrm{kg}$ Survanta; 4) $5 \mathrm{~mL} / \mathrm{kg}$ Exosurf (Burroughs Wellcome Company, Research Triangle Park, NC); and 5) $10 \mathrm{~mL} / \mathrm{kg}$ Exosurf. These represent standard and twice-standard surfactant doses that are used in the treatment of respiratory distress syndrome. Each milliliter of Survanta contains $25 \mathrm{mg}$ of phospholipid, approximately half of which is dipalmytoylphosphatidylcholine, whereas each milliliter of Exosurf contains $13.5 \mathrm{mg}$ of dipalmytoylphosphatidylcholine. The surfactant was administered via the distal pressuremonitoring lumen of the endotracheal tube in 1- to $3-\mathrm{mL}$ aliquots over a 5 - to 10 -min period. During the 20 - to 30 -s administration of individual aliquots, manual breaths with an anesthesia bag were given.

The piglets were ventilated for a total of $5 \mathrm{~h}$ after surfactant therapy. The ventilator settings were adjusted to maintain $\mathrm{PaO}_{2}$ levels of $10.66-16.00 \mathrm{kPa}(80-120 \mathrm{~mm}$ $\mathrm{Hg})$ and $\mathrm{PaCO}_{2}$ levels of $4-6.67 \mathrm{kPa}(30-50 \mathrm{~mm} \mathrm{Hg})$. If the animals required increasing amounts of oxygen, we alter- 
nated increases in $\mathrm{FiO}_{2}$ with increases in Paw. Paw was lowered preferentially when oxygen requirements diminished.

To assess the effects of therapy on gas exchange, we compared arterial blood gas measurements at 30,60,120, 240 , and $360 \mathrm{~min}$ after meconium administration. At these times, we recorded the distal $\mathrm{Paw}$ and the $\mathrm{PaCO}_{2}$ and calculated three measures of oxygenation: 1 ) the ratio of $\mathrm{PaO}_{2}$ to $\left.\mathrm{PAO}_{2} ; 2\right)$ the $\mathrm{PaO}_{2} / \mathrm{PAO}_{2}$ ratio divided by the distal Paw; and 3) the oxygenation index $\left[\left(\mathrm{FiO}_{2} \times 100 \times\right.\right.$ $\left.\left.\mathrm{Paw}) / \mathrm{PaO}_{2}\right]\right)$. We estimated the $\mathrm{PAO}_{2}\left[\left(\mathrm{FiO}_{2} \times 713 \mathrm{~mm}\right.\right.$ $\left.\mathrm{Hg})-\mathrm{PaCO}_{2}\right]$.

Airway fluid samples were obtained at time 0 (premeconium), $60 \mathrm{~min}$ after meconium insufflation, and $5 \mathrm{~h}$ after surfactant administration. We would instill $1.5 \mathrm{~mL}$ of $0.9 \%$ saline into the proximal end of the endotracheal tube and manually ventilate for $15 \mathrm{~s}$. An $8 \mathrm{~F}$ suction catheter was placed inside the endotracheal tube to a distance of $2 \mathrm{~cm}$ below the tip of the tube (approximately $3-4 \mathrm{~cm}$ above the carina), and negative pressure was continuously applied for $5 \mathrm{~s}$. The catheter was then rinsed with an additional $1.5 \mathrm{~mL}$ of $0.9 \%$ saline. The airway fluid was centrifuged at $150 \times g$ for $10 \mathrm{~min}$. The cellular debris was discarded, and the supernatant was frozen at $-70^{\circ} \mathrm{C}$ until analysis. Total protein levels, phospholipid phosphorus levels, and dynamic surface tension were measured on each sample. Total protein levels were evaluated by a modification of the method of Lowry et al. (9) (Pierce Chemical Co., Rockford, IL). We used a modification of the technique of Rouser et al. (10) for phospholipid phosphorus analysis. After freeze drying, the aspirate was brought to twice the original protein concentration and mixed with an equal volume of Survanta at concentrations of 5 and $10 \mathrm{mg} / \mathrm{mL}$ phospholipid to equal 2.5 and $5.0 \mathrm{mg} / \mathrm{mL}$ phospholipid, respectively, after dilution. The minimum surface tensions of these Survanta solutions were known and served as references. After mixture with the airway fluid supernatant at twice original protein concentrations, the solutions were gently rotated at $37^{\circ} \mathrm{C}$ in a water bath. Approximately $25 \mu \mathrm{L}$ were analyzed on a pulsating bubble surfactometer (Electronetics, Amherst, NY) as designed by Enhorning (11). The measurements of surface tension were performed at $37^{\circ} \mathrm{C}$ in humidified air with a maximum bubble radius of $0.55 \mathrm{~mm}$ maintained for $15 \mathrm{~s}$. Thereafter, the radius was pulsed between 0.45 and $0.55 \mathrm{~mm}$ for $5 \mathrm{~min}$ at a frequency of $0.33 \mathrm{~Hz}$. The pressure difference across the surface was continuously recorded, and the surface tension at minimum bubble radius was calculated electronically according to the law of Young and LaPlace and printed on a tape. The difference between the minimum surface tension of the control surfactant at 2.5 and $5.0 \mathrm{mg} / \mathrm{mL}$ and the airway aspirate specimen plus surfactant indicates "inhibition" of surfactant surface-tension-lowering capability. Each assay was performed in triplicate by an individual blinded to the particular piglet's therapy. The mean \pm SD of the surface tension for each measurement was recorded.
Tissue preparation. Five h after surfactant administration, euthanasia was accomplished with an overdose of pentobarbital $(80 \mathrm{mg} / \mathrm{kg})$ delivered i.v. Heparinized saline was infused through the internal jugular catheter followed by perfusion of $500 \mathrm{~mL}$ of $10 \%$ neutral buffered formaldehyde solution. Blood was allowed to escape through a bleed point (carotid artery catheter). Perfusion fixation in situ occurred while the lungs were inflated at a constant pressure of $1.93 \mathrm{kPa}\left(20 \mathrm{~cm} \mathrm{H}_{2} \mathrm{O}\right)$. The heart and lungs were removed en bloc. In a consistent manner for all piglets, a single individual took one section of lung from the midpoint of each of four lobes (cardiac and diaphragmatic lobes of both the right and left lung). The specimens were processed, embedded in paraffin, and stained with hematoxylin-eosin.

A pathologist blinded to the therapy of individual animals evaluated and scored the histologic specimens. All slides were scored using a previously described six-point, four-variable histopathologic scoring system (Table 1) (8). The variables were based on histologic alterations detected with light microscopy and included 1) atelectasis (collapse of alveoli), 2) exudative debris in the airway (presence of exudative or mucoid material in primary or terminal airways), 3) visible meconium (presence of meconium in airways or alveoli), and 4) alveolar inflammation [presence of inflammatory cells (primarily neutrophils) in alveoli]. A score from 0 to 6 was assigned for each of the four parameters in the four lung specimens from every animal. In addition, a total injury score (the sum of all four variables) was calculated for individual lung sections.

Data analysis. Repeated-measures analysis of variance was used to compare physiologic measurements (e.g. $\mathrm{PaO}_{2} / \mathrm{PAO}_{2}$ ratio) and the tracheal aspirate parameters (e.g. minimum surface tension) at different time periods. The ages and weights of the piglets were compared using $t$ test. In addition, the histologic scores were compared with the Kruskal-Wallis and the Mann-Whitney tests. Differences were considered significant at $p<0.05$.

\section{RESULTS}

There were no significant differences in the ages or the weights of the animals in the 10 groups, nor were there

Table 1. Histologic scoring system for evaluation of changes* associated with meconium aspiration (8)

\begin{tabular}{cll}
\hline Score & Focal changes & Diffuse changes \\
\hline 0 & None & None \\
1 & Minimal & None \\
2 & Mild & None \\
3 & Moderate & Minimal \\
4 & Severe & Mild \\
5 & Not applicable & Moderate \\
6 & Not applicable & Severe \\
\hline
\end{tabular}

* For every specimen, the presence of atelectasis, exudative debris, visible meconium, and alveolar inflammation was assessed and scored. A total injury score was also calculated that equaled the sum of the scores of these four parameters. 
Table 2. $\left(\mathrm{PaO}_{2} / \mathrm{PAO}_{2}\right) /$ Paw ratio (measure of oxygenation $)^{*}$

\begin{tabular}{|c|c|c|c|c|c|c|}
\hline $\begin{array}{c}\text { Ventilator } \\
\text { (surfactant therapy) }\end{array}$ & $\begin{array}{c}0 \text { min } \\
\text { (premeconium) }\end{array}$ & $\begin{array}{c}30 \text { min } \\
\text { after meconium }\end{array}$ & $\begin{array}{c}\quad 60 \mathrm{~min} \\
\text { (just before surfactant) }\end{array}$ & $120 \mathrm{~min} t$ & $240 \mathrm{~min}$ & $\begin{array}{c}360 \mathrm{~min} \\
(5 \mathrm{~h} \text { after surfactant })\end{array}$ \\
\hline PPV control (no surfactant) & $0.204(0.013)$ & $0.031(0.005)$ & $0.036(0.003)$ & $0.023(0.006)$ & $0.020(0.004)$ & $0.026(0.003)$ \\
\hline JET control (no surfactant) & $0.159(0.009)$ & $0.017(0.004)$ & $0.024(0.004)$ & $0.026(0.005)$ & $0.040(0.008)$ & $0.042(0.004)$ \\
\hline PPV Survanta $(4 \mathrm{~mL} / \mathrm{kg})$ & $0.218(0.010)$ & $0.029(0.004)$ & $0.031(0.003)$ & $0.031(0.006)$ & $0.066(0.007)$ & $0.064(0.003)$ \\
\hline JET Survanta (4 mL/kg) & $0.163(0.007)$ & $0.039(0.006)$ & $0.024(0.004)$ & $0.015(0.003)$ & $0.037(0.005)$ & $0.068(0.005)$ \\
\hline PPV Survanta $(8 \mathrm{~mL} / \mathrm{kg})$ & $0.229(0.011)$ & $0.048(0.004)$ & $0.050(0.006)$ & $0.049(0.007)$ & $0.068(0.007)$ & $0.092(0.007)$ \\
\hline JET Survanta $(8 \mathrm{~mL} / \mathrm{kg})$ & $0.150(0.003)$ & $0.029(0.005)$ & $0.046(0.004)$ & $0.043(0.007)$ & $0.061(0.007)$ & $0.078(0.006)$ \\
\hline PPV Exosurf ( $5 \mathrm{~mL} / \mathrm{kg})$ & $0.137(0.012)$ & $0.044(0.008)$ & $0.062(0.006)$ & $0.044(0.006)$ & $0.068(0.005)$ & $0.066(0.008)$ \\
\hline JET Exosurf (5 mL/kg) & $0.245(0.009)$ & $0.021(0.005)$ & $0.048(0.005)$ & $0.014(0.003)$ & $0.031(0.004)$ & $0.044(0.005)$ \\
\hline PPV Exosurf $(10 \mathrm{~mL} / \mathrm{kg})$ & $0.127(0.009)$ & $0.025(0.003)$ & $0.036(0.003)$ & $0.023(0.004)$ & $0.031(0.003)$ & $0.037(0.008)$ \\
\hline JET Exosurf $(10 \mathrm{~mL} / \mathrm{kg})$ & $0.229(0.014)$ & $0.022(0.001)$ & $0.049(0.005)$ & $0.043(0.004)$ & $0.085(0.006)$ & $0.097(0.013)$ \\
\hline
\end{tabular}

*Data are expressed as mean $( \pm \mathrm{SD})$. The $\left(\mathrm{PaO}_{2} / \mathrm{PAO}_{2} / \mathrm{Paw}\right.$ ratio was lower (4- to 10-fold) in all groups at 30 min after meconium $(p<0.016)$.

$\dagger$ This ratio was either unchanged or lower $1 \mathrm{~h}$ after surfactant.

differences between groups in blood pressure or heart rate during the investigation. After an initial increase in all animals, the Paw generally remained elevated for the $6 \mathrm{~h}$ of ventilation after meconium instillation. The $\mathrm{PaCO}_{2}$ values were generally maintained in the desired range of 4-6.67 $\mathrm{kPa}(30-50 \mathrm{~mm} \mathrm{Hg})$. In Table 2, the $\left(\mathrm{PaO}_{2} / \mathrm{PAo}_{2}\right) /$ Paw ratio is presented. This ratio decreased precipitously (4- to 10-fold) in all groups after meconium insufflation ( $p$ $<0.016)$. One $h$ after surfactant administration, the ratio was either unchanged or again declined. Over the remainder of the experiment, there was a slight, nonsignificant rise in this ratio, which never approached the premeconium value. The oxygenation index and the $\mathrm{PaO}_{2} / \mathrm{PAO}_{2}$ ratio also demonstrated a similar lack of response to surfactant therapy. The changes in these measures of oxygenation over time were comparable to those we have previously described in this model among animals not treated with surfactant (8).

In the airway fluid samples, total protein levels were increased at $1 \mathrm{~h}$ (Table $3, p<0.007$ ) after meconium insufflation, and these levels persisted for the duration of the study. By contrast, total phospholipid phosphorus levels declined after meconium administration (Table 4, $p$ $<0.0044$ ) with a return to baseline values or higher after surfactant therapy in all surfactant-treated groups except for the two JET groups given Survanta. Excluding the JET control animals, the minimum surface tension of the

Table 3. Supernatant total protein levels $(\mathrm{mg} / \mathrm{mL})$ of the tracheal aspirates*

\begin{tabular}{|c|c|c|c|}
\hline $\begin{array}{l}\text { Ventilator } \\
\text { (surfactant therapy) }\end{array}$ & $\begin{array}{c}0 \text { min } \\
\text { (premeconium) }\end{array}$ & $\begin{array}{c}60 \mathrm{~min} \\
\text { (just before } \\
\text { surfactant) }\end{array}$ & $\begin{array}{c}360 \mathrm{~min} \\
(5 \mathrm{~h} \text { after } \\
\text { surfactant })\end{array}$ \\
\hline PPV control & $0.80(0$ & $1.60(0.43)$ & $1.06(0.37)$ \\
\hline JET contro & $0.27(0.08)$ & $0.68(0.18)$ & 1.01 \\
\hline PPV Survanta (4 mL/kg) & $0.12(0.06)$ & $3.02(0.61)$ & $1.39(0.52)$ \\
\hline JET Survanta (4 mL/kg) & $0.21(0.05)$ & $0.96(0.20)$ & $1.20(0.37)$ \\
\hline PPV Survanta $(8 \mathrm{~mL} / \mathrm{kg})$ & $0.67(0.21)$ & $2.13(0.45)$ & $5.32(0.75)$ \\
\hline JET Survanta $(8 \mathrm{~mL} / \mathrm{kg})$ & $0.56(0$ & $1.24(0.26)$ & $1.06(0.18)$ \\
\hline PPV Exosurf ( $5 \mathrm{~mL} / \mathrm{kg})$ & $0.20(0.05)$ & $1.86(0.41)$ & $2.99(0.45)$ \\
\hline JET Exosurf $(5 \mathrm{~mL} / \mathrm{kg})$ & $0.29(0$. & $1.59(0.43)$ & $1.58(0.33)$ \\
\hline PPV Exosurf $(10 \mathrm{~mL} / \mathrm{kg})$ & $0.48(0.12)$ & $1.33(0.23)$ & $1.76(0.47)$ \\
\hline JET Exosurf $(10 \mathrm{~mL} / \mathrm{kg})$ & $0.52(0.09)$ & $1.84(0.35)$ & $1.72(0.47)$ \\
\hline
\end{tabular}

*Data are expressed as mean $( \pm \mathrm{SD})$. Total protein levels increased after meconium $(p<0.007)$ to levels that persisted. tracheal aspirates rose after meconium insufflation (Table $5, p<0.012$ ). However, despite general increases in total phospholipids after surfactant therapy, the elevation of surface tension values persisted throughout the experiment.

On histologic examination, atelectasis and inflammation were common findings (Figs. 1 and 2). Plugs of meconium were frequently found in the larger airways (Fig. 1), whereas inflammatory cells could be found both within alveoli and within the interstitium (Fig. 2). All the JET piglets receiving surfactant, except for the group receiving $4 \mathrm{~mL} / \mathrm{kg}$ of Survanta, had significantly less atelectasis than the JET control animals (Fig. $3 A, p<$ 0.024), whereas no PPV animals had less atelectasis than the PPV control group. Both PPV Exosurf groups had significantly less meconium present than the PPV control and PPV Survanta subjects (Fig. $3 B, p<0.011$ ). There were no significant differences between groups in the inflammation scores (Fig. $3 C$ ), the airway exudate scores (Fig. $3 D$ ), or the total injury scores (Fig. $3 E$ ).

Five of the surfactant-treated animals had clinical evidence of pulmonary hemorrhage (Fig. 4) manifested by copious bloody secretions (as much as $20-30 \mathrm{~mL}$ ) and worsening blood gases. These hemorrhages tended to occur during the last $1-2 \mathrm{~h}$ of the experiment. The bleeding could not be attributed the type or dose of surfactant or to a particular ventilator.

Table 4. Total phospholipid phorphorus levels ( $\mu \mathrm{g} / \mathrm{mL}$ ) of the tracheal aspirates*

\begin{tabular}{|c|c|c|c|}
\hline $\begin{array}{c}\text { Ventilator } \\
\text { (surfactant therapy) }\end{array}$ & $\begin{array}{c}0 \mathrm{~min} \\
\text { (premeconium) }\end{array}$ & $\begin{array}{c}60 \mathrm{~min} \\
\text { (just before } \\
\text { surfactant) }\end{array}$ & $\begin{array}{c}360 \mathrm{~min} \\
(5 \mathrm{~h} \text { after } \\
\text { surfactant) }\end{array}$ \\
\hline PPV control (no surfactant) & $3.63(1.60)$ & $3.70(1.52)$ & $3.76(1.49)$ \\
\hline JET control (no surfa & $7.35(2$ & $7.31(3.11)$ & 4.90 \\
\hline PPV Survanta $(4 \mathrm{~mL} / \mathrm{kg})$ & $5.78(2.31)$ & $5.21(2.25)$ & $11.41(4.04)$ \\
\hline JET Survanta $(4 \mathrm{~mL} / \mathrm{kg})$ & $8.29(3$ & $5.06(2.79)$ & $4.09(1.80)$ \\
\hline PPV Survanta $(8 \mathrm{~mL} / \mathrm{kg})$ & $9.13(3.31)$ & $6.94(2.61)$ & $11.09(3.11)$ \\
\hline JET Survanta $(8 \mathrm{~mL} / \mathrm{kg})$ & $11.79(4.21)$ & $4.59(2.70)$ & $6.17(3.02)$ \\
\hline PPV Exosurf ( $5 \mathrm{~mL} / \mathrm{kg})$ & $6.38(3.11)$ & $5.79(2.70)$ & $13.33(3.82)$ \\
\hline JET Exosurf $(5 \mathrm{~mL} / \mathrm{kg})$ & $7.62(2.79)$ & $2.52(1.65)$ & $9.58(3.18)$ \\
\hline PPV Exosurf $(10 \mathrm{~mL} / \mathrm{kg})$ & $8.59(3.00)$ & $5.89(2.33)$ & $16.53(4.95)$ \\
\hline JET Exosurf $(10 \mathrm{~mL} / \mathrm{kg})$ & $12.51(3.22)$ & $5.99(2.68)$ & $11.77(3.40)$ \\
\hline
\end{tabular}

${ }^{*}$ Data are expressed as mean $( \pm \mathrm{SD})$. Phospholipid phosphorus levels declined after meconium $(p<0.0044)$, but increased after surfactant. 
Table 5. Minimum surface tension $(\mathrm{mN} / \mathrm{mL})$ of the tracheal aspirates at $5 \mathrm{mg} / \mathrm{mL}$ Survanta*

\begin{tabular}{lccc}
\hline $\begin{array}{c}\text { Ventilator } \\
\text { (surfactant therapy) }\end{array}$ & $\begin{array}{c}0 \text { min } \\
\text { (premeconium) }\end{array}$ & $\begin{array}{c}60 \mathrm{~min} \\
\text { (just before } \\
\text { surfactant) }\end{array}$ & $\begin{array}{c}360 \mathrm{~min} \\
(5 \mathrm{~h} \text { after } \\
\text { surfactant) }\end{array}$ \\
\hline PPV control (no surfactant) & $17.1(3.2)$ & $22.0(5.4)$ & $23.3(4.8)$ \\
JET control (no surfactant) & $18.4(3.7)$ & $14.4(5.8)$ & $16.7(3.3)$ \\
PPV Survanta (4 mL/kg) & $15.3(4.8)$ & $26.6(6.2)$ & $27.6(5.5)$ \\
JET Survanta (4 mL/kg) & $13.3(6.2)$ & $16.6(3.9)$ & $14.2(3.6)$ \\
PPV Survanta $(8 \mathrm{~mL} / \mathbf{k g}$ ) & $16.4(5.4)$ & $21.0(4.9)$ & $26.3(6.0)$ \\
JET Survanta $(8 \mathrm{~mL} / \mathbf{k g})$ & $19.9(4.3)$ & $21.2(5.6)$ & $22.2(4.4)$ \\
PPV Exosurf $(5 \mathrm{~mL} / \mathbf{k g})$ & $17.4(5.6)$ & $27.1(6.0)$ & $22.4(4.9)$ \\
JET Exosurf $(5 \mathrm{~mL} / \mathbf{k g})$ & $19.9(6.0)$ & $22.9(5.1)$ & $25.1(5.5)$ \\
PPV Exosurf $(10 \mathrm{~mL} / \mathbf{k g})$ & $20.2(3.9)$ & $25.2(4.6)$ & $23.4(5.0)$ \\
JET Exosurf $(10 \mathrm{~mL} / \mathbf{k g}$ ) & $20.3(5.2)$ & $24.3(4.7)$ & $22.3(5.4)$ \\
\hline
\end{tabular}

*Data are expressed as mean $( \pm \mathrm{SD})$. Surface tension levels generally rose after meconium and remained at the elevated levels.

\section{DISCUSSION}

In this model of MAS, newborn piglets were treated with different doses of two commercially available surfactants, as well as with conventional ventilation or JET. Based on these therapies, we found little difference in our ability to oxygenate the animals. Furthermore, there were minimal differences between groups in the histologic parameters we assessed. In the airway aspirates, meconium insufflation produced a persistent increase in the total protein level and surface tension. Surfactant therapy resulted in elevation of airway phospholipid levels but no decrease of the surface tension.

We previously compared the response of a piglet model of MAS with conventional and three types of highfrequency ventilation (8). In that investigation, we similarly found few differences in physiologic parameters (oxygenation, etc.). However, there were less severe histologic alterations in the high-frequency jet-ventilated compared with PPV-ventilated piglets. The histologic scores for the various parameters in the current investigation were similar to those of our previous work.

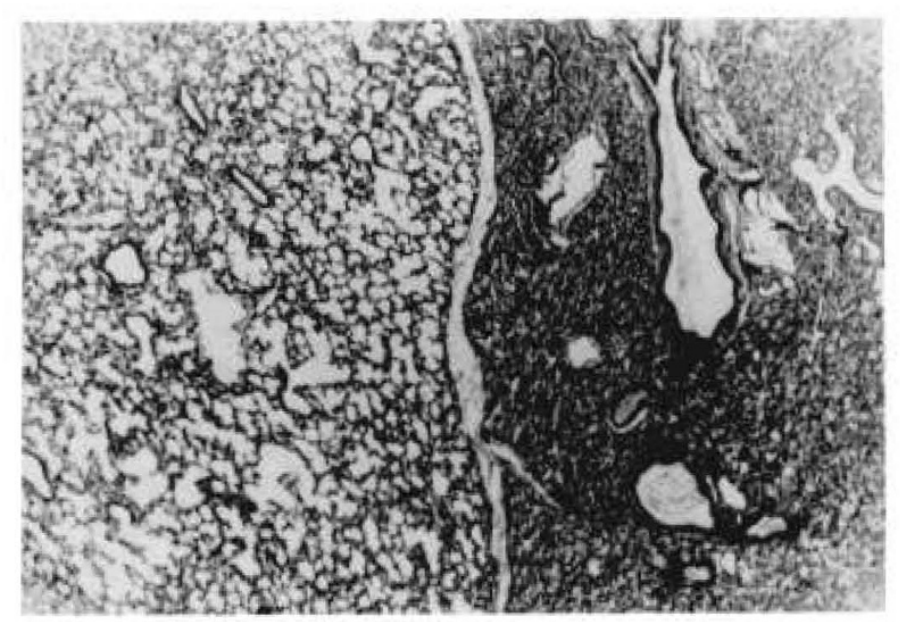

Figure 1. Section of lung with normal expansion next to a focal area of atelectasis. Note the plugs of meconium in the atelectatic section (hematoxylin-eosin, magnification $\times 15$ ).

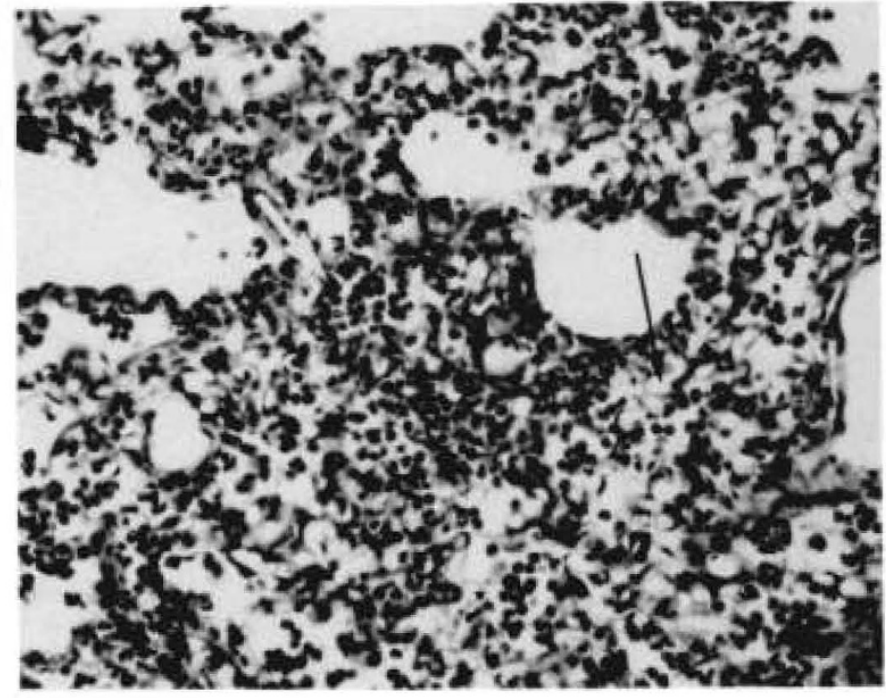

Figure 2. Inflammation centered around bronchioles. The inflammatory infiltrate is mainly neutrophilic (white arrow) and is within both alveoli and the interstitium. Empty capillaries are present due to the perfusion fixation process (black arrow) (hematoxylin-eosin, magnification $\times 300)$.

Based on the in vitro work of Moses et al. (5) and others $(3,4)$, there appears to be an inhibition of surfactant function by meconium. Several investigators have reported anecdotal experience with surfactant therapy in human neonates with severe MAS $(6,7,12)$. In these reports, improved oxygenation was found after surfactant therapy alone $(6,12)$ or in combination with JET (7). Of note, these latter investigators used surfactant different from the Survanta and Exosurf that we used. Perhaps inherent differences in the preparations affected the response in our model of MAS. In addition, the infants in the aforementioned reports were treated at mean ages of $24-48 \mathrm{~h}$, rather than earlier in the course of their respiratory illness. One of the investigators was unable to demonstrate sustained improved oxygenation with conventional ventilation (7) but was able to do so with concomitant JET. To date, there are no published randomized or controlled trials of human infants affected with MAS treated with any type of surfactant.

Paranka et al. (13) treated their piglet model of MAS with Survanta lavage and found improved oxygenation compared with controls. By contrast, Pauly et al. (14) were unable to demonstrate either improved oxygenation or improved pulmonary mechanics after surfactant therapy (Survanta or Exosurf) in their piglet model of MAS.

Why have some of the human and animal experiences demonstrated a beneficial response to surfactant therapy for MAS whereas other studies have not? We speculate there may be a number of factors involved. Perhaps there is a species difference (humans versus pigs) in the response. Our model of MAS is a pure aspiration model without chronic in utero hypoxemia and stress. The nature of the disorder that is experimentally produced may be vastly different from that of the sickest infants with MAS. These latter babies may have persistent pulmonary 


\section{A. ATELECTASIS}
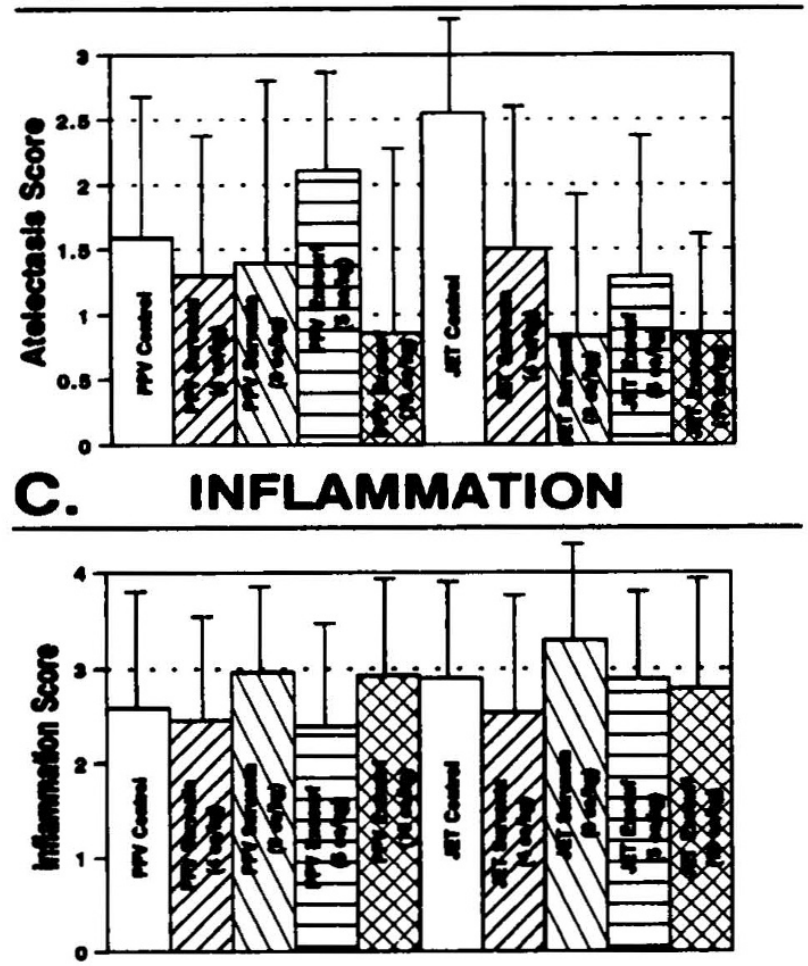

E. TOTAL SCORE

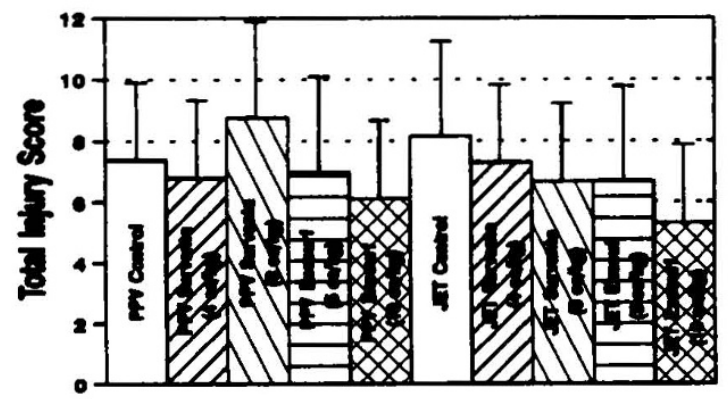

B. MECONIUM PRESENCE

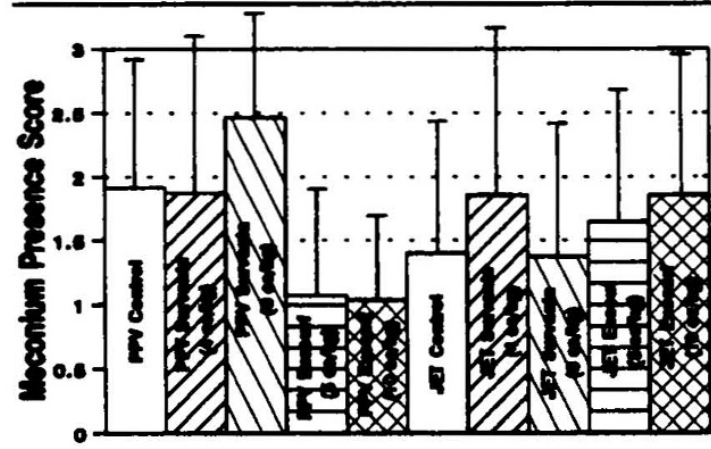

D. AIRWAY EXUDATE

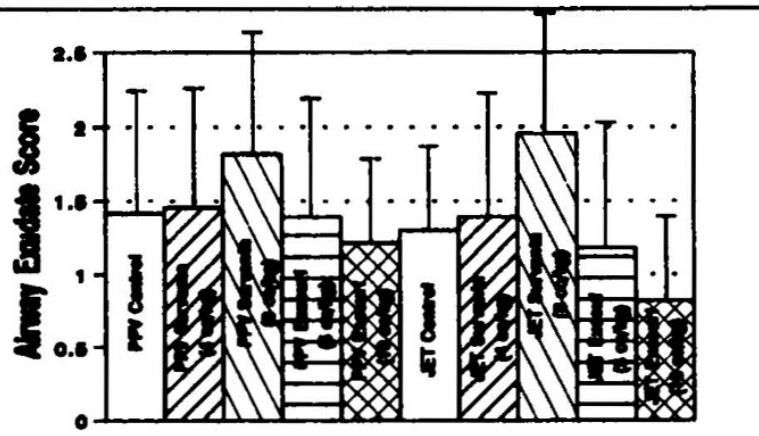

Figure 3. Although we present the histologic parameters as the mean ( \pm SD) scores of the lung sections, the scores were compared with nonparametric analysis. $A$, All JET groups, except for JET Survanta at $4 \mathrm{~mL} / \mathrm{kg}$, had less atelectasis than JET controls $(p<0.024)$, whereas no PPV surfactant-treated groups had less atelectasis than the PPV controls. $B$, Both PPV Exosurf groups had significantly less meconium present than the PPV control and PPV Survanta subjects $(p<0.011)$. $C$, There were no significant differences in the inflammation scores. $D$, There were no significant differences in the airway exudate scores. $E$, There were no significant differences in the total injury scores.

hypertension with either hyperreactive or remodeled pulmonary vasculature (increased muscular wall thickness) (15). Furthermore, we treated early in the course of the disorder ( $1 \mathrm{~h}$ after meconium), whereas human infants have been treated at $24-48 \mathrm{~h}$ of age $(6,7,12)$. The nature of the disorder may be very different after that amount of time and may be responsive to surfactant. As the course of MAS progresses, the early obstructive effects of meconium that impair gas exchange may not be as important as inflammation, mediator release, and pulmonary vasoreactivity. Furthermore, in these human anecdotal reports a different type of surfactant was used. There may be a difference among infants with MAS in the response to this substance compared with Survanta and Exosurf.
Additionally, because of the nonhomogeneous character of MAS due to obstructive phenomena, there may have been nonuniform distribution of the surfactant that was administered. Nevertheless, we did not find grossly overdistended areas microscopically, which would have been the histologic manifestation of airways that preferentially received surfactant. A different method of administering surfactant therapy (such as in an aerosolized form) might lead to more homogeneous distribution. Conceivably, treatment with saline or surfactant lavage in a manner similar to that used by Paranka et al. (13), followed by surfactant therapy, could result in improved oxygenation.

Despite airway phospholipid phosphorus levels equal to or greater than those before meconium insufflation, 


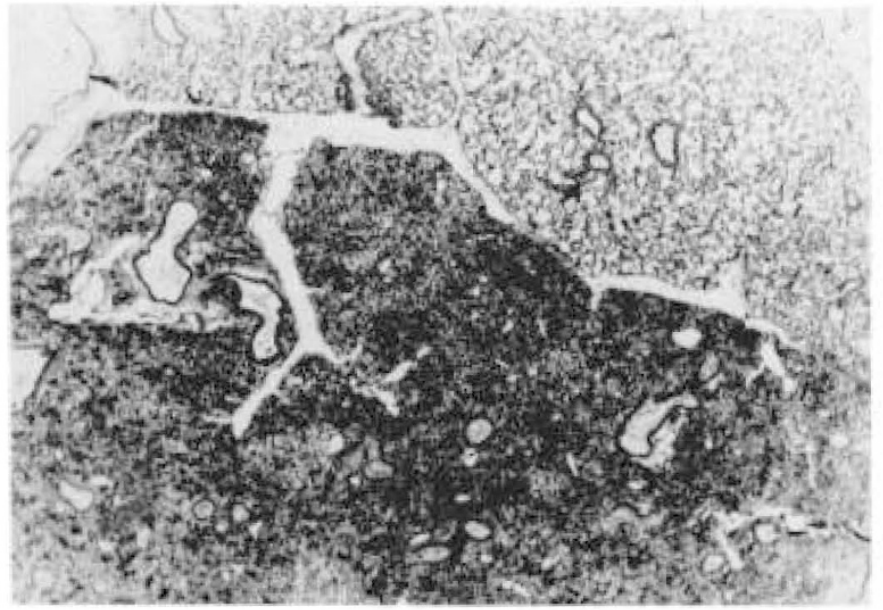

Figure 4. Diffuse hemorrhage is present in this section of the lung and is confined by interlobular septa. Plugs of meconium are in the larger airways (hematoxylin-eosin, magnification $\times 15$ ).

surface tension levels remained elevated in our animals, suggesting an ongoing surfactant dysfunction. The work of Moses et al. (5) supports improvement by increasing the amount of administered exogenous surfactant. Perhaps by using even higher doses of Exosurf or Survanta, we could see a beneficial response. However, some piglets did not tolerate twice the standard dose of these substances well (they became transiently cyanotic) and we wonder how they or human neonates would respond to even greater amounts.

In this model, total phospholipid levels in our airway aspirates decreased after meconium insufflation. We are unsure about the specific mechanism of this decline. Meconium may substantially inactivate surfactant. The inactivated substance may be rapidly removed, resulting in the initially low phospholipid levels. Although the phospholipid levels generally rose by the end of the experiment, they remained low in the two JET Survanta groups. Although histologically these two groups did not have more meconium present, there may have been ongoing inactivation of endogenous and exogenous surfactant.

The mean initial surface tension levels (Fig. $2 C$ ) for all groups were between 13 and $20 \mathrm{mN} / \mathrm{m}$. These may seem relatively high, although others have found similar levels in different species (16). The measurements made on our specimens were performed in triplicate by a blinded, experienced researcher. The levels were consistently in this range. The samples were obtained from tracheal aspirates, not from smaller airways or alveoli. This may have further influenced the measured levels. The recent workshop of the National Heart, Lung, and Blood Institute that two of us participated in (T.E.W. and T.A.M.) (17) addressed the potential problems with interpretation of data from upper airway compared with bronchoalveolar secretions.

Neither of the surfactants we administered contain surfactant-associated protein A. This protein has been shown to counteract the inhibitory effects of some proteins and may be critical for improvement of infants with severe respiratory failure (18). Lotze et al. (19) have found that surfactant protein A concentrations in tracheal aspirate fluid increase as infants receiving extracorporeal membrane oxygenation improve. Thus, this protein's presence may be critical for optimal function of exogenous surfactant therapy.

We are aware that many clinicians treat neonates with MAS using exogenous surfactant therapy. However, we believe more animal investigations are needed, followed by controlled, prospective, human trials, to adequately determine whether exogenous surfactant therapy is of proven benefit for the disorder.

Acknowledgments. The authors thank Audrey Chang, Ph.D., and Robin Howard, M.S., for their statistical assistance. We thank Burroughs Wellcome and Ross Laboratories for their donation of Exosurf and Survanta, respectively, used in this project. Finally, we thank Mallinckrodt Critical Care for supplying the endotracheal tubes with distal monitoring lumens.

\section{REFERENCES}

1. Wiswell TE, Bent RC 1993 The meconium aspiration syndrome: unanswered questions. Pediatr Clin North Am 40:955-981

2. Tyler DC, Murphy J, Cheney FW 1978 Mechanical and chemical damage to lung tissue caused by meconium aspiration. Pediatrics $62: 454-459$

3. Chen CT, Young TJK, Rogers MC 1985 Effect of intra-alveolar meconium on pulmonary surface tension properties. Crit Care Med 13:233-236

4. Clark DA, Nieman GF, Thompson JE, Paskanik AM, Rokhar JE, Bredenberg CE 1987 Surfactant displacement by meconium free fatty acids: an alternative explanation for atelectasis in meconium aspiration syndrome. J Pediat 110:765-770

5. Moses D, Holm BA, Spitale P, Liu M, Enhorning G 1991 Inhibition of pulmonary surfactant function by meconium. Am J Obstet Gynecol 164:477481

6. Auten RL, Notter RH, Kendig JW, Davis JM, Shapiro DL 1991 Surfactant treatment of full-term newborns with respiratory failure. Pediatrics 87:101 107

7. Davis JM, Richter SE, Kendig JW, Notter RH 1992 High-frequency jet ventilation and surfactant treatment of newborns with severe respiratory failure. Pediatr Pulmonol 13:108-112

8. Wiswell TE, Foster NH, Slayter MV, Hachey WE 1992 Management of a piglet model of the meconium aspiration syndrome with high-frequency or conventional ventilation. Am J Dis Child 146:1287-1293

9. Lowry OH, Rosebrough NJ, Farr AL, Randall RJ 1951 Protein measurement with the Folin phenol reagent. J Biol Chem 193:265-275

10. Rouser G, Fleischer S, Yamamoto A 1970 Two-dimensional thin layer chromatographic separation of polar lipids and determination of phospholipids by phosphorus analysis of spots. Lipids 5:494-496

11. Enhorning G 1977 Pulsating bubble technique for evaluating pulmonary surfactant. J Appl Physiol 43:198-203

12. Khammash HM, Perlman M, Wojtulewicz J, Dunn MS 1993 Surfactan therapy in full-term neonates with severe respiratory failure. Pediatrics 92:135-139

13. Paranka MS, Walsh WF, Stancombe BB 1992 Surfactant lavage in a piglet model of meconium aspiration syndrome. Pediatr Res 31:625-628

14. Pauly TH, Berry DD, Whitehead VL, Smith MS 1992 Artificial surfactant in the treatment of meconium aspiration syndrome (MAS). Pediatr Res 31:319A(abstr 1898)

15. Goetzman BW 1992 Meconium aspiration. Am J Dis Child 146:1282-1283

16. Jobe A, Ikegami M 1987 Surfactant for the treatment of respiratory distress syndrome. Am Rev Respir Dis 136:1256-1275

7. Boat TF, Tepper R, Stecenko A, et al. (there were 25 participants) 1993 NHLBI Workshop Summary: assessment of lung function and dysfunction in studies of infants and children. Am Rev Respir Dis 148:1105-1108

18. Hallman M, Merritt TA, Akino T, Bry K 1991 Surfactant protein A, phosphatidylcholine and surfactant inhibitors in epithelial lining fluid: correlation with surface activity, severity of RDS, and outcome of small premature infants. Am Rev Respir Dis 144:1376-1384

19. Lotze A, Whitsett JA, Kammerman LA, Ritter M, Taylor GA, Short BL 1990 Surfactant protein A concentrations in tracheal aspirate fluid from infants requiring extracorporeal membrane oxygenation. J Pediatr 116:435-440 